\title{
Effects of replacing soybean meal with slow-release urea on milk production of Holstein dairy cows
}

\author{
S. Hallajian ${ }^{1}$, J. Fakhraei ${ }^{1 \#}$, H.M. Yarahamdi ${ }^{1}$ \& K.J. Khorshidi ${ }^{2}$ \\ ${ }^{1}$ Department of Animal Science, Arak Branch, Islamic Azad University, Arak, Iran \\ ${ }^{2}$ Department of Animal Science, Qaemshahr Branch, Islamic Azad University, Qaemshahr, Iran
}

(Submitted 10 January 2020; Accepted 28 October 2020; Published 7 January 2021)

\begin{abstract}
Copyright resides with the authors in terms of the Creative Commons Attribution 4.0 South African License.
See: http://creativecommons.org/licenses/by/4.0/za

Condition of use: The user may copy, distribute, transmit and adapt the work, but must recognize the authors and the South African Journal of Animal Science.
\end{abstract}

\begin{abstract}
The study investigated the effects of replacing soybean meal (SBM) with slow-release urea (SRU) on milk production, milk composition, and rumen fermentation of Holstein dairy cows. Sixteen Holstein cows weighing between 550 and $680 \mathrm{~kg}$ in mid lactation were randomly assigned to four dietary treatments in a 12-week study. The treatments consisted of T1: a diet containing 16.7\% crude protein (CP), T2: T1 with $0.5 \%$ SRU replacing plant protein, T3: T1 with $0.75 \%$ SRU replacing plant protein, and T4: T1 with $1.00 \%$ SRU replacing plant protein. Animals were fed three times a day with feed being offered ad libitum. Dry matter intake (DMI) and average daily gain (ADG) were not affected by the level of SRU. Feeding SRU did not affect milk production and milk composition significantly, but milk fat and milk urea nitrogen (MUN) levels were increased. Significant differences were observed in ruminal volatile fatty acid (VFA) concentration. Feeding SRU increased butyrate concentration with no significant effects on concentrations of acetate or propionate. Significant differences were observed in cholesterol, triglyceride, high-density lipoprotein (HDL), low-density lipoprotein (LDL), and nonesterified fatty acid (NEFA) concentrations, but glucose, very-lowdensity lipoprotein (VLDL) and $\beta$-hydroxybutyrate (BHB) levels were not affected significantly by the treatments. Thus, feeding SRU altered the release rate of ammonia and provided more ammonia nitrogen $\left(\mathrm{NH}_{3}-\mathrm{N}\right)$ for microbial protein synthesis in the rumen.
\end{abstract}

Keywords: ammonia, microbial protein, milk composition, milk urea nitrogen, rumen fermentation, urea, \#Corresponding author: fakhraeijafar@gmail.com

\section{Introduction}

Soybean meal (SBM) is the most widely used protein supplement for the nutrition of the dairy cows, because of its high quality and high protein content (Gidlund et al., 2015). Soybean meal is produced from the residue after oil extraction. It has a desirable amino acid balance and high essential amino acid concentrations, and can be used as a protein source (Lopes et al., 2017). But in recent years, because of the high price of concentrates, and an increase in production costs, the use of other protein sources has increased (Imaizumi et al., 2015). The use of non protein nitrogen (NPN) as a protein replacement in ruminant diets appeals to the industry (Golombeski et al., 2006). Ruminants can use these products as a source of nitrogen $(\mathrm{N})$ for microbial synthesis. Nitrogen compounds are decomposed by rumen microbial enzymes, and microorganisms can use these products to make their own proteins (microbial proteins) to produce milk (Broderick et al., 2009; Highstreet et al., 2010; Gardinal et al., 2017). Urea is the NPN compound that is used most because it is readily available and costs less than protein sources such as SBM (Gonçalves et al., 2014; Gardinal et al., 2016; Joysowal et al., 2019). The amount of urea that can be used is limited because of its toxicity (Huntington et al., 2006; Kertz, 2010; Saleem et al., 2012). If excessive ureais used, because of its rapid conversion to ammonia, ammonia concentration increases rapidly within the first hour of consumption (Taylor-Edwards et al., 2009) and the conversion rate of urea to ammonia is faster than the uptake of ammonia by rumen microbes, causing ammonia to escape from the rumen. Nitrogen that is needed for microbial protein synthesis in the urine is lost, ammonia accululates, and the animal is poisoned (Löest et al., 2001; Golombeski et al., 2006; Ayasan, 2009). As a result, urea hydrolyzation increases rumen $\mathrm{pH}$, allows ammonia to be absorbed into the blood, and causes advanced ammonia toxicity and disorders 
such as muscle contraction, skin vibration, excessive saliva secretion, frequent urination and faeces, fast breathing, animal imbalance, and finally death. Chaveiro et al. (2011) conducted research in dairy cows and concluded that using a high concentration of urea reduces fertility.

Many experiments have been conducted to control the release of urea in the rumen and maximize microbial utilization of ammonia. Some researchers used microbial urease inhibitors, and concluded that inhibitors may reduce urea activity, but provide only short-term regulation (Ludden et al., 2000). Another approach was to use slow-release urea products such as biuret, urea-formaldehyde, urea phosphate, and urea calcium, which release urea slowly in the rumen (Golombeski et al., 2011). Highstreet et al. (2010) suggested that replacing urea with SRU in dairy cows improved the nitrogen efficiency in the rumen because these products have a low dissolution rate and release ammonia slowly. If nitrogen is released slowly in the rumen, fibre digestion may be improved (Alvarez-Almora et al., 2012), and fibre-degrading bacteria are better able to utilize rumen $\mathrm{NH}_{3}-\mathrm{N}$. In an in vitro study, Cherdthong et al. (2011) reported that supplementation of urea-calcium sulfate mixture reduceD rumen $\mathrm{NH}_{3}-\mathrm{N}$ concentration and improveD microbial population better than feed grade urea.

The effects of replacing SBM with SRU in Holstein dairy cows have not been investigated extensively, and the consequences of replacing true protein sources with SRU in diets with various levels of concentrate are not clear. Therefore the aim of this study was to investigate the effects on milk production, milk composition, and rumen fermentation of replacing SBM partially with SRU in the diets of Holstein dairy cows at three levels of concentrate.

\section{Materials and Methods}

All procedures were approved by the Ethics Committee of Islamic Azad University, Arak Branch (Markazi, Iran) (No. IAAU, 1504). Sixteen Holstein dairy cows weighing between 550 and $680 \mathrm{~kg}$ in mid lactation ( $80 \pm 30$ days in lactation) were randomly assigned to four dietary treatments (four replicates or cows) in a completely randomized design and a 12-week study. The cows were housed in individual stalls, allowing them free access to clean water. Each treatment consisted of a 21-day adjustment, and a 7-day collection. Treatments consisted of T1: control diet in which 57\% SBM was included, T2: control diet supplemented with $0.5 \% \mathrm{SRU}$, T3: control diet supplemented with $0.75 \% \mathrm{SRU}$, and T4: control diet supplemented with $1 \%$ SRU (Table 1). Animals were fed three times a day. The control diet was formulated according to NRC (2001) nutrient recommendations for Holstein dairy cows (Table 2). The diets contained $16.7 \%$ crude protein, $6.77 \mathrm{Mcal} / \mathrm{kg}$ net energy for lactation, $15 \%$ dietary dry matter corn silage, $20 \%$ alfalfa hay, and $55 \%$ concentrate mix. To analyse the chemical composition of the diets, the samples were dried in a forced ventilation oven at $55^{\circ} \mathrm{C}$ for 72 hours, and then ground in a Wiley-type mill with a $1-\mathrm{mm}$ sieve to determine the dry matter (DM), CP, ash, and organic matter contents of the feed ingredients according to AOAC (2000). Analyses of acid detergent fibre (ADF) and neutral detergent fibre (NDF) were performed (Van Soest \& Mason, 1991).

To determine the initial bodyweight (IBW), and final bodyweight (FBW), all cows were weighed at the beginning and end of the experiment. The average daily weight (ADG) was obtained from the difference between IBW and FBW, divided by the number of days in the feedlot.

Cows were milked mechanically three times a day at $05 \mathrm{~h} 00,13 \mathrm{~h} 00$, and $21 \mathrm{~h} 00$. Samples of the milk were mixed well and frozen at $4{ }^{\circ} \mathrm{C}$ to analyse fat, lactose, solids-not-fat, and protein contents (Ekomilk TOTAL milk analyser). Milk urea nitrogen (MUN) was determined with an automated colorimetric assay (Broderick \& Clayton, 1997).

After the adjustment period and in the last week of the experiment, samples of rumen fluid were collected by oesophageal tube three hours after feeding, and the samples were filtered through double layers of cheesecloth. Immediately, $\mathrm{pH}$ was determined with a digital $\mathrm{pH}$ meter (Horiba Twin B-213, Spectrum Technologies Inc., Aurora, IL, USA). Then $10 \mathrm{ml}$ ruminal sample was mixed with $2 \mathrm{ml} 25 \%$ (wt/vol) metaphosphoric acid, centrifuged at $20,000 \times \mathrm{g}$ for $15 \mathrm{~min}$ at $4{ }^{\circ} \mathrm{C}$, and frozen at $-20^{\circ} \mathrm{C}$ for VFA (Erwin et al., 1961 ) and $\mathrm{NH}_{3}-\mathrm{N}$ analyses. Volatile fatty acid concentration was determined by gas chromatography (Varian 3600 Star, Varian Specialties, Midland, ON, Canada) with a $0.25 \mathrm{~mm}$ id $\times 30 \mathrm{~m}$ column, according to Ichihara \& Fukubayashi (2010) and $\mathrm{NH}_{3}-\mathrm{N}$ concentration was determined (Broderick \& Kang, 1980).

On day 30 after giving birth, cows were assigned to begin presynch injections of prostaglandin F2alpha (PGF2 $\alpha$ ), given 14 days apart. Twelve days after the second injection, the ovsynch programme was performed by injecting gonadotropin-releasing hormone $(\mathrm{GnRH})$ (Kara et al., 2011). All animals were inseminated 16 hours after the second GnRH injection (Sarkar et al., 2010). The day after the first GnRH injection and on the day of insemination, a pregnancy rate diagnosis was performed by ultrasonography (Aloka ${ }^{\circledR}$ SSD-500, Aloka, Wallingford, CT, USA), and the follicle diameters of the cows were determined. 
Table 1 ingredients and nutrient composition of experimental diets for Holstein dairy cows

\begin{tabular}{lrrrr}
\hline Ingredient (\% of DM) & \multicolumn{1}{c}{ T1 } & T2 & T3 \\
\hline Slow-release urea & 0.00 & 0.50 & 0.75 & 1.00 \\
Alfalfa hay 17\% CP & 21.26 & 20.00 & 20.00 & 20.00 \\
Corn silage 8.5\% CP & 15.00 & 15.00 & 15.00 & 15.00 \\
Wheat straw 4.7\% CP & 10.00 & 10.00 & 10.00 & 10.00 \\
Barley & 20.81 & 22.72 & 22.72 & 27.35 \\
Fat powder & 3.79 & 4.21 & 4.21 & 4.62 \\
Wheat bran & 5.00 & 5.98 & 5.73 & 5.37 \\
Soybean meal 44\% CP & 19.48 & 15.79 & 15.79 & 11.78 \\
Beet molasses & 2.00 & 2.00 & 2.00 & 2.00 \\
Phosphorus supplement & 1.00 & 1.00 & 1.00 & 1.00 \\
Calcium carbonate & 1.09 & 1.18 & 1.18 & 1.22 \\
Salt & 0.12 & 0.07 & 0.07 & 0.02 \\
Sodium bicarbonate & 0.45 & 0.55 & 0.55 & 0.64
\end{tabular}

CP: crude protein; T1: $16.7 \%$ crude protein diet, T2: $16.7 \%$ CP diet with $0.50 \%$ slow-release urea replacing plant protein, T3: $16.7 \%$ CP diet with $0.75 \%$ slow-release urea replacing plant protein, T4: a $16.7 \%$ CP diet with $1.00 \%$ slow-release urea replacing plant protein

Table 2 Chemical composition and feed formulation of experimental diets for Holstein dairy cows supplemented with slow-release urea

\begin{tabular}{|c|c|c|c|c|}
\hline Ingredient & T1 & T2 & T3 & T4 \\
\hline Dry matter, \% & 82.50 & 81.56 & 80.56 & 81.8 \\
\hline Net energy lactation, MJ/kg & 6.98 & 6.77 & 6.77 & 6.77 \\
\hline Crude protein, \% & 16.70 & 16.70 & 16.70 & 16.70 \\
\hline RDP, \% & 11.47 & 11.92 & 11.92 & 12.35 \\
\hline RUP, \% & 5.23 & 4.78 & 4.78 & 4.35 \\
\hline Ash, \% & 6.70 & 6.46 & 6.46 & 6.22 \\
\hline Calcium, \% & 1.00 & 1.00 & 1.00 & 1.00 \\
\hline Phosphorus, \% & 0.46 & 0.45 & 0.45 & 0.45 \\
\hline NDF, \% & 34.19 & 34.12 & 34.12 & 33.51 \\
\hline eNDF, \% & 24.42 & 27.48 & 27.48 & 27.26 \\
\hline Ether extract, \% & 4.60 & 3.80 & 3.50 & 4.20 \\
\hline
\end{tabular}


Blood samples were collected twice a day from each cow before feeding fand three hours afterwards through a jugular vein by venoject tubes containing sodium heparin. Blood samples were centrifuged at 3500 $\times \mathrm{g}$ for $20 \mathrm{~min}$ at $4{ }^{\circ} \mathrm{C}$. After centrifugation, the plasma was removed and stored at $-20{ }^{\circ} \mathrm{C}$ to determine biochemical parameters. Concentrations of plasma glucose, cholesterol, triglyceride, HDL, LDL and VLDL were determined with commercial kits (Pars Azmoon kits, Pars Azmoon, Tehran, Iran) and an automated chemistry analyser (Dirui CS-400, Changchun, China) (Jeshari et al., 2016). Progesterone concentration was determined with an enzyme-linked immunosorbent assay (ELISA) kit (Enzo Life Sciences Inc, NY, USA), according to Munro and Stabenfeldt (1984) with some modifications. $\beta$-Hydroxybutyrate concentration was determined with an enzymatic method with standard kits (Randox, catalogue nos FA 115 and 30t) (Gibbard \& Watkins, 1968). Nonesterified fatty acid (NEFA) concentration was determined with an enzymatic assay with standard kits (Randox, catalogue no RB 1007) (Johnson \& Peters, 1993).

All analyses were performed using analysis of variance with PROC GLM and PROC MIXED of SAS software (SAS Institute Inc., Cary, North Carolina, USA). Comparisons of means were performed using the Tukey-Kramer method at $5 \%$ significant level. The statistical model for variables measured once was:

$$
Y_{i j}=\mu+T_{i}+\varepsilon_{i j}
$$

Where: $Y_{i j}$ is the observation measured on the jth cow assigned to the ith diet,

$\mu$ is the overall mean effect,

$T_{i}$ is the ith diet effect and

$\varepsilon_{i j}$ is the random error associated with the jth cow assigned to the ith diet.

For repeated measurement variables, the statistical model was :

$$
Y_{i j k}=\mu+T_{i}+a_{i(j)}+D_{k}+(T D)_{i k}+\varepsilon_{i j k}
$$

Where: $Y_{i j k}$ is the variable record measured at time $k$ on the jth cow assigned to the ith diet,

$\mu$ is the overall mean effect,

$\mathrm{Ti}$ is the ith fixed diet effect,

$a_{i j}$ is the random effect of jth cow within the ith diet,

$D_{k}$ is the fixed kth time effect when measurement was taken, and

$(T D)_{i k}$ is the fixed interaction effect between diet and time, and

$\varepsilon_{\mathrm{ijk}}$ is the random residual effect.

\section{Results and Discussion}

The results showed that replacing SBM partially with SRU did not affect BW $(P>0.05)$. Similarly, Neal et al. (2014) reported that feeding diet containing $0.49 \%$ SRU did not show significant differences in BW and daily feed intake of dairy cows. Based on the results, during early lactation, cows were in negative energy balance, and their bodyweight did not increase. But in contrast, cows in the later days after calving were able to reach positive energy balance that made the condition better for bodyweight gain.

In this experiment, the authors observed no significant differences in DMI in treatments $(P>0.05)$ (Table 3), though DMI was higher in the cows fed diets containing SRU. Corte et al. (2018) conducted the same research in Nellore steers and observed no difference in DMI. In contrast, Galina et al. (2003) conducted similar research on sixty zebu steers and reported that supplementing $1.8 \mathrm{~g} / \mathrm{kg}$ DM SRU improved DMI and digestibility. Puga et al. (2001) conducted the same research in cannulated sheep and reported that supplementing controlled-release urea with sugar cane tops or corn stubble with forage to CRU ratios at 70:30 increased DMI compared with the control diet significantly. Many mechanisms showed how NPN affected feed intake. Over $20 \mathrm{gr} / \mathrm{kg}$ urea concentration may reduce DMI in urea treatments (Patra \& Aschenbach, 2018). Rapid hydrolysis of urea causes ammonia to be absorbed by the rumen epithelium and may result in ammonia poisoning (Huntington et al., 2006; Ayasan, 2009; Ribeiro et al., 2011). But in this experiment, $\mathrm{NH}_{3}-\mathrm{N}$ concentration was below the toxic level and improved rumen degradation and voluntary intake. Also, the hepatic urea cycle may cause oxidative metabolism in the liver, which increases ATP production and affects feed intake (Allen, 2000; Benedeti et al., 2014).

There were no significant differences in average milk production from the addition of SRU (Table 4). Galo et al. (2003) conducted similar research on lactating Holstein dairy cows and concluded that milk production was not affected when SBM was replaced partially by SRU. The same result was observed by Giallongo et al. (2015), who found that replacing SBM with SRU did not affect NDF digestibility or milk production. In contrast, Tikofsky and Harrison (2007) reported that milk production increased in cows fed diets containing optigen. The lack of differences in milk yield between treatments indicates that partial 
replacement of SBM with SRU was successful because the negative effects of urea were not observed and the lack of differences in milk yield may be related to the low inclusion rate of SRU. Slow-release urea decreases the nitrogen excretion in the urine and improves nitrogen utilization by supplying $\mathrm{NH}_{3}-\mathrm{N}$ to rumen bacteria as a source of nitrogen for amino acid synthesis, and enhances milk production by improving the absorption of amino acids in the small intestine. This could explain the higher milk production of dairy cows in the later days of lactation.

Table 3 Dry matter intake and bodyweight of Holstein dairy cows fed diets containing slow-release urea

\begin{tabular}{lrrrrrr}
\hline Parameter & \multicolumn{1}{c}{ T1 } & \multicolumn{1}{c}{ T2 } & T3 & T4 & SE & $P$-value \\
\hline Initial bodyweight, kg & 589.40 & 593.33 & 614.85 & 620.28 & 27.54 & 0.816 \\
Final bodyweight, kg & 614.83 & 629.25 & 654.85 & 672.23 & 26.27 & 0.445 \\
Average daily gain, kg/day & 0.36 & 0.51 & 0.57 & 0.74 & 0.036 & 0.330 \\
Dry matter intake, kg/day & $20 / 76$ & 20.82 & 21.21 & 21.42 & 0.352 & 0.511
\end{tabular}

CP: crude protein; T1: 16.7\% CP diet; T2: 16.7\% CP diet with 0.50\% slow-release urea replacing plant protein; T3: $16.7 \%$ CP diet with $0.75 \%$ slow-release urea replacing plant protein; T4: $16.7 \%$ CP diet with $1.00 \%$ slow-release urea replacing plant protein

Replacing SBM partially with SRU significantly increased milk fat concentration (Table 4). Golomobeski et al. (2006) and Ayasan et al. (2011) reported similar results in which the milk fat level was higher for the cows fed SRU as a supplement than the control group. Similarly Xin et al. (2010) reported that milk fat levels were higher for cows fed diets containing encapsulated urea. They found that the increase in milk fat may have been related to lower $\mathrm{NH}_{3}-\mathrm{N}$ or increased acetate to propionate ratio in the rumen. In contrast, Inostroza et al. (2010) observed that feeding a diet containing $114 \mathrm{~g} / \mathrm{kg}$ DM SRU did not have a significant effect on milk fat and milk protein concentrations of dairy cows. In the current experiment, milk fat concentration was higher in SRU diets. This could be related to a change in the proportion of rumen cellulolytic microorganisms. Unlike proteolytic bacteria, which use amino acids and peptides as a protein source, cellulolytic bacteria can use urea sources such as ammonia more efficiently. So increasing nitrogen sources for cellulolytic bacteria has an important effect on acetate and fat production (Golombeski et al., 2006; Xin et al., 2010).

Table 4 Effect of diets containing slow-release urea on milk yield and milk composition of Holstein dairy cows

\begin{tabular}{lrrrrrr}
\hline Parameter & T1 & T2 & T3 & T4 & SE & $P$-value \\
\hline Milk yield, kg/day & 33.96 & 34.27 & 33.92 & 33.28 & 0.429 & 0.442 \\
Fat, kg/day & 2.88 & 3.64 & 3.19 & 3.44 & 0.043 & $<0.001$ \\
Protein, kg/day & 3.21 & 3.13 & 3.13 & 3.23 & 0.025 & 0.112 \\
Lactose, kg/day & 4.77 & 4.76 & 4.77 & 4.77 & 0.009 & 0.164 \\
Solids non-fat, kg/day & 8.70 & 8.62 & 8.72 & 8.87 & 0.061 & 0.144 \\
Milk urea nitrogen, \% & 12.20 & 12.40 & 12.60 & 13.20 & 0.52 & 0.04
\end{tabular}

CP: crude protein; T1: 16.7\% CP diet; T2: 16.7\% CP diet with 0.50\% slow-release urea replacing plant protein; T3: $16.7 \%$ CP diet with $0.75 \%$ slow-release urea replacing plant protein; T4: $16.7 \%$ CP diet with $1.00 \%$ slow-release urea replacing plant protein

Milk protein was not affected significantly by replacing SBM partially with SRU $(P>0.05)$ (Table 4). Although SNF levels were higher for T4 than the other groups, supplementing diets with SRU did not have a significant effect on milk lactose, and SNF levels on various days of the experiment $(P>0.05)$ (Table 4). It seems that SRU sources could not affect milk lactose directly, because nitrogen and protein sources of the diet affected mainly the blood nitrogen content, milk, and urine, and not milk sugar and lactose levels. 
Feeding SRU improves microbial protein production, which provides the energy content in the early days of lactation. In many cases, feeding SRU increased milk protein, because concentrations of SRU supplemented with carbohydrate sources provided the protein requirements of dairy cows and increased milk protein (Broderick et al., 2009; Ayasan et al., 2011).

Milk urea nitrogen concentration was higher for the SRU group, but MUN values were in the normal range of 10 to $14 \mathrm{mg} / \mathrm{dl}(P<0.05)$ (Table 4) (Cherdthong \& Wanapat, 2010; Ayasan et al., 2011). Many parameters are associated with MUN concentrations at various stages of lactation, such as differences in DMI, rumen microbial adaptation, and absorptive capacity of the rumen (Godden et al., 2001). In another study, Ayasan et al. (2011) reported that MUN concentration was correlated significantly with SNF levels. Also, overfeeding protein diets had a negative impact on MUN concentration (Olmos Colmenero \& Broderick, 2006).

Replacing SBM partially with SRU released $\mathrm{NH}_{3}-\mathrm{N}$ to the rumen at a slower rate than urea. Therefore, supplementing SRU into diets improved fermentation by providing enough $\mathrm{NH}_{3}-\mathrm{N}$ for bacterial utilization and microbial protein synthesis (Cherdthong et al., 2011). Similar results were observed by Taylor-Edwards et al. (2009), Highstreet et al. (2010), Ribeiro et al. (2011), and Benedeti et al. (2014). In contrast, Galo et al. (2003) reported that feeding polymer-coated urea to dairy cows did not affect microbial protein production in the rumen.

Volatile fatty acid concentrations of ruminal fluid, such as acetate and propionate, were different between treatments. In the first ten days, acetate concentration was different between treatments $(P<0.05$, whereas in days 20 to 80 the authors found no differences $(P>0.05)$. Also, on days 20,40,60, and 80, no differences were observed in propionate concentration between treatments $(P>0.05)$. Unlike acetate and propionate, the concentration of butyrate was significantly different. Butyrate concentration was higher for the control group, but lower in the cows fed T2 and T4 $(P<0.05)$. On days 10, 20, and 70, there was a significant difference in the valerate concentration of rumen fluid $(P<0.05)$. Cows fed the control diet had the lowest valerate concentration (Table 5). Gonzalez-Munoz et al. (2019) conducted similar research on dairy cows and concluded that replacing SBM with SRU increased $\mathrm{NH}_{3}-\mathrm{N}$ and VFA concentration. Similarly, Firkins et al. (2007) reported that feeding polyurethane-coated urea or feed-grade urea to dairy cows did not have a negative effect on rumen fermentation and altered the VFA concentration. In other experiments, researchers reported that feeding SRU diets did not affect VFA concentration or total VFA (Taylor-Edwards et al., 2009; Xin et al., 2010; Sabbia et al., 2012). Fibre-degrading bacteria such as Ruminococcus albus generally produce acetate and some, such as Fibrobacter succinogenes, produce propionate as the main product of fermentation (Russell, 2002; Cherdthong et al., 2011). In addition, degradation of structural carbohydrates is normally slower than the degradation of non-structural carbohydrates (Sevim \& Önol, 2019), and these bacteria have an important requirement for ammonia (Hristov \& Ropp, 2003). It is possible that SRU provided more nitrogen to fibre-degrading bacteria and their fermentation products such as acetate and propionate increased.

Table 5 Effect of diets containing slow-release urea on rumen fermentation parameters of Holstein dairy cows

\begin{tabular}{lcccccc}
\hline Parameter & T1 & T2 & T3 & T4 & SEM & $P$-value \\
\hline $\mathrm{pH}$ & 6.45 & 6.38 & 6.41 & 6.36 & 0.07 & 0.974 \\
Ammonia & 15.7 & 14.2 & 13.7 & 13.1 & 2.54 & 0.090 \\
Acetate & 61.56 & 62.13 & 65.33 & 62.77 & 4.38 & 0.931 \\
Propionate & $18.69^{\mathrm{b}}$ & $20.02^{\mathrm{b}}$ & $19.74^{\mathrm{b}}$ & $23.32^{\mathrm{a}}$ & 0.73 & 0.086 \\
Butyrate & 12.6 & 11.6 & 12.2 & 10.6 & 0.41 & 0.002 \\
Valerate & $1.39^{\mathrm{a}}$ & $2.17^{\mathrm{a}}$ & $1.83^{\mathrm{b}}$ & $1.48^{\mathrm{b}}$ & 0.14 & 0.026
\end{tabular}

\footnotetext{
${ }^{a, b}$ Within rows, means with a common superscript were not different with probability $P=0.05$

CP: crude protein; T1: $16.7 \%$ crude protein (CP) diet; T2: $16.7 \%$ CP diet with $0.50 \%$ slow-release urea replacing plant protein; T3: $16.7 \%$ CP diet with $0.75 \%$ slow-release urea replacing plant protein; T4: $16.7 \%$ CP diet with $1.00 \%$ slowrelease urea replacing plant protein
}

At the time of feeding in the early morning and three hours after feeding, plasma glucose concentrations were not different between treatments $(P>0.05)($ Table 6$)$. However, between the two blood 
sampling times, the concentration of blood glucose was the highest in T3. In contrast, Gardinal et al. (2017) conducted an experiment in Nellore steers and found that glucose concentration increased in cows fed diets containing polymer-coated SRU. Blood urea concentration is correlated with the amount of urea produced by the liver from the degradation of amino acids in the liver (Piccione et al., 2007). It is possible that higher glucose concentration for urea is associated with hepatic gluconeogenesis. Feeding urea would increase gluconeogenesis, which decreases insulin and increases plasma glucose concentration (Huntington et al., 2006).

Table 6 Effect of diets containing slow-release urea on blood serum parameters of Holstein dairy cows

\begin{tabular}{llcccccc}
\hline Time & Parameter & T1 & T2 & T3 & T4 & SEM & $P$-value \\
\hline \multirow{3}{*}{ Before feeding } & Glucose, mg/dl & 68.47 & 68.63 & 71.81 & 70.63 & 1.79 & 0.506 \\
& Cholesterol, mg/dl & $162.77^{\mathrm{a}}$ & $158.86^{\mathrm{a}}$ & $161.44^{\mathrm{a}}$ & $150.26^{\mathrm{b}}$ & 2.55 & 0.015 \\
& Triglyceride, mg/dl & $94.02^{\mathrm{b}}$ & $102.89^{\mathrm{a}}$ & $96.16^{\mathrm{b}}$ & $94.21^{\mathrm{b}}$ & 1.29 & 0.006 \\
& HDL, $\mathrm{mg} / \mathrm{dl}$ & $84.16^{\mathrm{b}}$ & $100.29^{\mathrm{a}}$ & $88.90^{\mathrm{b}}$ & $87.07^{\mathrm{c}}$ & 1.22 & $<0.0001$ \\
& LDL, mg/dl & $64.44^{\mathrm{b}}$ & $88.28^{\mathrm{a}}$ & $67.75^{\mathrm{b}}$ & $63.99^{\mathrm{b}}$ & 2.25 & $<0.0001$ \\
& VLDL, mg/dl & 68.47 & 68.82 & 71.81 & 70.66 & 1.78 & 0.52 \\
& Glucose, $\mathrm{mg} / \mathrm{dl}$ & 70.77 & 73.50 & 74.08 & 74.95 & 1.64 & 0.344 \\
& Cholesterol, mg/dl & $157.34^{\mathrm{a}}$ & $155.08^{\mathrm{a}}$ & $154.83^{\mathrm{a}}$ & $146.21^{\mathrm{b}}$ & 1.91 & 0.003 \\
& Triglyceride, mg/dl & $91.05^{\mathrm{ab}}$ & $92.72^{\mathrm{a}}$ & $93.09^{\mathrm{a}}$ & $88.56^{\mathrm{b}}$ & 1.00 & 0.017 \\
& HDL, $\mathrm{mg} / \mathrm{dl}$ & $59.13^{\mathrm{b}}$ & $67.70^{\mathrm{a}}$ & $63.42^{\mathrm{ab}}$ & $63.94^{\mathrm{ab}}$ & 1.41 & 0.003 \\
& LDL, mg/dl & $59.00^{\mathrm{b}}$ & $82.45^{\mathrm{a}}$ & $58.51^{\mathrm{b}}$ & $59.92^{\mathrm{b}}$ & 1.84 & 0.001 \\
& VLDL, mg/dl & 70.77 & 73.50 & 74.08 & 74.95 & 1.64 & 0.344
\end{tabular}

\footnotetext{
a,b Within rows, means with a common superscript were not different with probability $P=0.05$

CP: crude protein; T1: $16.7 \%$ crude protein (CP) diet; T2: 16.7\% CP diet with $0.50 \%$ slow-release urea replacing plant protein; T3: $16.7 \%$ CP diet with $0.75 \%$ slow-release urea replacing plant protein; T4: $16.7 \%$ CP diet with 1.00\% slowrelease urea replacing plant protein; HDL: high density lipoprotein, LDL: low density lipoprotein, VLDL: very low density lipoprotein
}

Cholesterol concentration differed between treatments $(P<0.05)$. At the first blood sampling and three hours afterwards, T1 had the highest cholesterol concentration, and T4 the lowest $(150.26 \mathrm{mg} / \mathrm{dL})(P<0.05)$ (Table 6). Decreased cholesterol concentration may be because of the utilization of carbon skeletons of fatty acids and sugars, which are used to make unnecessary amino acids by urea-derived amines. In contrast, Mousavi Seyyed Ali Kia et al. (2019) reported that feeding SRU to Holstein lactating cows did not have a significant effect on blood cholesterol concentration.

In the current experiment, the authors observed that triglyceride concentrations differed between treatments $(P<0.05)$ (Table 6). T2 showed the highest triglyceride concentration before the morning feeding $(102.89 \mathrm{mg} / \mathrm{dL})$. There was also a significant difference in blood triglyceride concentration three hours after feeding. Cows fed T4 had the lowest triglyceride concentration, whereas the highest concentration was for cows in T3.

HDL concentration differed between treatments $(P<0.05)$ before feeding and three hours afterwards. Cows fed the control diet had the lowest HDL concentration $(84.16 \mathrm{mg} / \mathrm{dL})$. HDL concentration was highest for cows fed T2 (100.29 mg/d) (Table 6).

Before morning feeding, and three hours post feeding, a significant difference was found in LDL concentration between treatments $(P<0.05)$. The cows fed $0.5 \%$ SRU before morning feeding had the highest plasma LDL concentration $(88.28 \mathrm{mg} / \mathrm{dl})$, and the cows fed T4 had the lowest plasma LDL concentration (63.99 mg/dL) (Table 6).

Unlike HDL, and LDL, there was no significant difference in VLDL concentration of plasma at prefeeding and three hours afterwards $(P>0.05)$. However, cows fed T3 and T4 showed a higher VLDL concentration of plasma than other treatments (Table 6).

There was a significant difference in nonesterified fatty acid (NEFA) concentration in treatments $(P$ $<0.05$ ) (Table 7). T1 had the highest NEFA concentration, and cows fed T3 and T4 had the lowest NEFA concentrations of plasma $(0.153$ and $0.159 \mathrm{mmol} / \mathrm{dL})$. The BHB concentration was not significantly different between treatments $(P>0.05)$. These metabolites are related to the energy condition of animals. The higher 
concentrations of NEFA in T1 may have been because of the increase in lipoprotein synthesis in the liver, which is used to metabolize NEFA during lipolysis. In T4, trigelycerol metabolization and hepatic synthesis of LDLs, which are required for NEFA metabolization, would be expected tp be lower. So, along with NEFA, the BHB concentration will be decreased because less NEFA is used to produce ketone bodies (Piccioli-Cappelli et al., 2014). These results indicate that different SRU concentrations could change the condition for energy balance and prevent negative energy balance, especially in the first lactating months. Metabolic changes in plasma concentration cause negative energy balance in dairy cows after giving birth because of the high levels of energy and dietary protein. These changes could cause pathologic disorders such as hypoglycaemia, ketonemia, and increased NEFA concentration, which may have a negative effect on their pregnancy.

Table 7 Concentrations of plasma $\beta$-hydroxybutyrate and nonesterified fatty acid of cows fed diets containing slow-release urea

\begin{tabular}{llllllc}
\hline Parameter & T1 & T2 & T3 & T4 & SEM & $P$-value \\
\hline $\begin{array}{l}\text { Nonesterified fatty acids } \\
\beta \text {-Hydroxybutyrate }\end{array}$ & $0.181^{\mathrm{a}}$ & $0.153^{\mathrm{b}}$ & $0.166^{\mathrm{a}}$ & $0.159^{\mathrm{b}}$ & 0.002 & $<0.0001$ \\
& 0.277 & 0.255 & 0.270 & 0.273 & 0.006 & 0.139
\end{tabular}

\footnotetext{
${ }^{a, b}$ Within rows, means with a common superscript were not different with probability $P=0.05$

CP: crude protein; T1: $16.7 \%$ crude protein (CP) diet; T2: $16.7 \% \mathrm{CP}$ diet with $0.50 \%$ slow-release urea replacing plant protein; T3: $16.7 \%$ CP diet with $0.75 \%$ slow-release urea replacing plant protein; T4: $16.7 \%$ CP diet with 1.00\% slowrelease urea replacing plant protein
}

Miranda et al. (2019) reported that there were no differences in most of the blood parameters when cows were fed various urea sources. Similar results were observed by Calomeni et al. (2015), who recorded no differences in blood parameters when SBM was replaced partially with protein sources such as yeastderived microbial protein or SRU.

The diameter of the ovulatory follicle differed between treatments $(P<0.5)$. Cows fed T2 had larger follicles than cows fed the other diets $(18.11 \pm 0.61 \mathrm{~mm}$ versus $15.47 \pm 0.61 \mathrm{~mm}, 17.47 \pm 0.61 \mathrm{~mm}$ and $16.46 \pm 0.61 \mathrm{~mm}$ for T1, T3 and T4, respectively). Higher levels of SRU in T3 and T4 produced similar follicle diameters, and T1 had significantly smaller follicles than T3. Several studies reported that excessive urea has an adverse effect on fertility (Sinclair et al., 2012; Dawuda et al., 2002). Because of the correlation between follicular fluid and blood serum, increased serum urea levels may increase the follicular fluid urea and influence the oocyte quality (Tamminga, 2006). Therefore feeding SRU diets improves reproduction performance by preventing negative effects of urea in dairy cows (Westwood et al., 2000). Tamminga (2006) also observed a correlation between follicle size and urea level in dairy cows and reported that small and medium follicles had higher urea levels than large follicles. Besides, feeding excess dietary protein to dairy cows increases MUN levels and nitrogen excretion in the urine. These factors were found to be the risk factors of delayed conception in dairy cows (Guo et al., 2004). In other experiments, researchers reported a correlation between high MUN concentration and reduced conception rate (Melendez et al., 2000; RajalaSchultz et al., 2001; Hammon et al., 2005).

The results showed that progesterone concentration was different between treatments $(P<0.05)$. Before feeding and three hours afterwards, cows fed T1 had a lower progesterone concentration than those supplemented with SRU (Table 8). There is a correlation between MUN levels and progesterone concentration. High MUN is associated with low progesterone and reduced conception rate. In this study, cows fed SRU diets had higher MUN concentration than the control groups, but MUN values were in the normal range of 10 to $14 \mathrm{mg} / \mathrm{dl}$. So supplementing SRU into diets did not have a negative effect on reproductive performance. Some studies suggest that NEFA have a negative effect on progesterone levels (Jorritsma et al., 2003). They reported that high NEFA concentration reduced fertility by depressing progesterone concentration. In another experiment, Ghojoghi et al. (2013) reported that progesterone concentration was inversely associated with follicle size. They observed that progesterone concentration was lower in the cows with large follicles and cows with small follicles had the highest progesterone concentration. Similar results were observed by Nishimoto et al. (2009) and Tabatabaei et al. (2011). 


\begin{tabular}{lccccrrr}
\hline Sampling of Time & T1 & T2 & T3 & T4 & SEM & $P$-value \\
\hline Before feeding & $1.85^{\mathrm{a}}$ & $2.55^{\mathrm{a}}$ & $2.35^{\mathrm{a}}$ & $2.30^{\mathrm{a}}$ & 0.082 & 0.016 \\
3 hours after feeding & $2.35^{\mathrm{b}}$ & $3.80^{\mathrm{a}}$ & $3.75^{\mathrm{a}}$ & $3.65^{\mathrm{a}}$ & 0.043 & $<0.001$ \\
& & & & & & &
\end{tabular}

\footnotetext{
${ }^{a, b}$ Within rows, means with a common superscript were not different with probability $P=0.05$ CP: crude protein; T1: $16.7 \%$ crude protein (CP) diet; T2: $16.7 \%$ CP diet with $0.50 \%$ slow-release urea replacing plant protein; T3: $16.7 \%$ CP diet with $0.75 \%$ slow-release urea replacing plant protein; T4: $16.7 \%$ CP diet with $1.00 \%$ slowrelease urea replacing plant protein
}

\section{Conclusion}

Feeding SRU controlled the release rate of ammonia and improved rumen fermentation by providing more $\mathrm{NH}_{3}-\mathrm{N}$ for microbial protein synthesis in the rumen. The levels of milk production and DMI were not significantly higher for the cows fed diets supplemented with SRU compared with T1. Supplementation of SRU increased serum progesterone concentration and the diameter of the ovulatory follicle compared with T1. Thus, SBM could be replaced partially with SRU to reduce the feed costs without harming livestock production.

\section{Acknowledgements}

This work was supported by Islamic Azad University, Arak Branch (Markazi, Iran).

\section{Authors' Contributions}

JF, HMY \& KJK proposed the project and wrote the manuscript and SH conducted it

\section{Conflict of Interest Declaration} There is no conflict of interest.

\section{References}

Allen, M.S., 2000. Effects of diet on short-term regulation of feed intake by lactating dairy cattle. J. Dairy. Sci. 83, 15981624. https://doi.org/10.3168/jds.S0022-0302(00)75030-2.

Alvarez Almora, E.G., Huntington, G. \& Burns, J.C., 2012. Effects of supplemental urea sources and feeding frequency on ruminal fermentation, fiber digestion, and nitrogen balance in beef steers. J. Anim. Feed. Sci. Technol. 171, 136-145. https://doi.org/10.1016/j.anifeedsci.2011.10.012.

AOAC, 2000. Official methods of analysis. Association of Official Analytical Chemistss, Inc., Arlington, Virginia, USA.

Ayasan, T., 2009. Importance of milk urea nitrojen in dairy cow nutrition. J. Fac. Agr. Gaziosmanpaşa-U. 26, 27-33 (in Turkish).

Ayasan, T., Hizli, H. \& Yazgane, E., 2011. The effect of milk urea nitrogen on milk composition in Holstein dairy cows. Eurasian. J. Vet. Sci. 27, 219-222 (in Turkish).

Ayasan, T., Hizli, H., Yazgane, E., Kara, U. \& Gok, K., 2011. The effect of somatic cell count on milk urea nitrogen and milk composition. Kafkas Univ Vet Fac J, 17, 659-662. (in Turkish).

Benedeti, P.D.B., Paulino, P.V.R., Marcondes, M.I., Valadares Filho, S.C., Martins, T.S., Lisboa, E.F., Silva, L.H.P., Teixeira, C.R.V. \& Duarte, M.S., 2014. Soybean meal replaced by slow release urea in finishing diets for beef cattle. J. Livest. Sci. 165, 51-60. https://doi.org/10.1016/j.livsci.2014.04.027.

Broderick, G.A. \& Clayton, M.K., 1997. A statistical evaluation of animal and nutritional factors influencing concentrations of milk urea nitrogen. J. Dairy. Sci. 80, 2964-2971. https://doi.org/10.3168/jds.S0022-0302(97)76262-3.

Broderick, G.A. \& Kang, J.H., 1980. Automated simultaneous determination of ammonia and total amino acids in ruminal fluid and In vitro media. J. Dairy. Sci. 63, 64-75. https://doi.org/10.3168/jds.S0022-0302(80)82888-8.

Broderick, G.A., Stevenson, M.J. \& Patton, R.A., 2009. Effect of dietary protein concentration and degradability on response to rumen-protected methionine in lactating dairy cows. J. Dairy Sci. 92, 2719-2728. https://doi.org/10.3168/jds.2008-1277.

Calomeni, D.G., Gardinal, R., Venturelli, B.C., Freitas Junior, J.E.D., Vendramini, T.H.A., Takiya, C.S, Souza, H.N.D. \& Rennó, F.P., 2015. Effects of polymer-coated slow-release urea on performance, ruminal fermentation, and blood metabolites in dairy cows. J. R. Bras. Zootec. 44, 327-334. http://dx.doi.org/10.1590/S1806-92902015000900004.

Chaveiro, A.E., Andrade, M., Borba, A.E.S. \& Moreira da Silva, F., 2011. Association between plasma and milk urea on the insemination day and pregnancy rate in early lactation dairy cows. J. Physiol. Pharmacol. Adv. 1, 9-14. http://hdl.handle.net/10400.3/2617.

Cherdthong, A. \& Wanapat, M., 2010. Development of urea products as rumen slow-release feed for ruminant production: A review. Aust. J. Basic. Appl. Sci 4, 2232-2241.

Cherdthong, A., Wanapat, M. \& Wachirapakorn, C., 2011. Effects of urea-calcium mixture in concentrate containing high cassava chip on feed intake, rumen fermentation and performance of lactating dairy cows fed on rice straw. J. Livest. Sci. 136, 76-84. https://doi.org/10.1016/j.livsci.2010.08.002. 
Corte, R.R., Brito, F.O., Leme, P.R., Pereira, A.S.C., Freitas, J.E., Rennó, F.P., Silva, S.L., Tedeschi, L.O. \& Nogueira Filho, J.C.M., 2018. The effects of partial substitution of soybean with urea or slow-release urea on finishing performance, meat quality, and digestion parameters of Nellore steers. J. Anim. Prod. Sci. 58, $2242-2248$. https://doi.org/10.1071/AN16609.

Dawuda, P.M., Scaramuzzi, R.J, Leese, H.J., Hall, C.J., Peters, A.R., Drew, S.B. \& Wathes, D.C., 2002. Effect of timing of urea feeding on the yield and quality of embryos in lactating dairy cows. J. Theriogenology 58. 1433-1455. https://doi.org/10.1016/S0093-691X(02)00973-1.

Erwin, E., Marco, G. \& Emery, E., 1961. Volatile fatty acid analyses of blood and rumen fluid by gas chromatography. J. Dairy Sci. 44,1768-1771. https://doi.org/10.3168/jds.s0022-0302(61)89956-6.

Firkins, J.L., Yu, Z. \& Morrison, M., 2007. Ruminal nitrogen metabolism: Perspectives for Integration of microbiology and nutrition for dairy. J. Dairy Sci. 90, E1-E16. https://doi.org/10.3168/jds.2006-518.

Galina, M.A., Perez-Gil, F., Ortiz, R.M.A., Hummel, J.D. \& Ørskov, R.E., 2003. Effect of slow release urea supplementation on fattening of steers fed sugar cane tops (Saccharum officinarum) and maize (Zea mays): Ruminal fermentation, feed intake and digestibility. J. Livest. Prod. Sci. 83, 1-11. https://doi.org/10.1016/S03016226(03)00045-9.

Galo, E., Emanuele, S.M., Sniffen, C.J., White, J.H. \& Knapp, J.R., 2003. Effects of a polymer-coated urea product on nitrogen metabolism in lactating Holstein dairy cattle. J. Dairy. Sci. 86, $2154-2162$. https://doi.org/10.3168/jds.S0022-0302(03)73805-3.

Gardinal, R, Calomeni, G.D., Consolo, N.R.B., Takiya, C.S., Freitas Júnior, JE., Gandra, J.R., Vendramini, T.H.A., Souza., H.N. \& Renno, F.P., 2017. Influence of polymer-coated slow release urea on total tract apparent digestibility, ruminal fermentation and performance of Nellore steers. Asian-Aust. J. Anim. Sci. 30, 34-41. https://doi.org/10.5713/ajas.16.0058.

Gardinal, R., Gandra, J.R., Calomeni, G.D., Vendramini, T.H.A, Takiya, C.S., Freitas Junior, J.E., Souza, H.N. \& Renno, F.P., 2016. Effects of polymer- coated slow-release urea on ruminal fermentation and nutrient total tract digestion of beef steers. J. R. Bras. Zootec. 45, 63-70. https://doi.org/10.1590/S1806-92902016000200004.

Ghojoghi, S., Samadi, F. \& Hasani, S., 2013. Comparison of blood serum biochemical compositions and ovarian follicular fluid of different-sized follicles in dairy cows. Research on Animal Production 4(7), 9-2013. http://rap.sanru.ac.ir/browse.php?a_code=A-10-1-58\&slc_lang=en\&sid=1

Giallongo, F., Hristov, A.N., Oh, J., Frederick, T., Weeks, H., Werner, J., Lapierre, H., Patton, R.A., Gehman, A. \& Parys, C., 2015. Effects of slow-release urea and rumen-protected methionine and histidine on performance of dairy cows. J. Dairy. Sci. 98, 3292-3308. https://doi.org/10.3168/jds.2014-8791.

Gibbard, S. \& Watkins, P.J. 1968. A micro-method for the enzymatic determination of D- $\beta$-hydroxybutyrate and acetoacetate. 19, 511-521. https://doi.org/10.1016/0009-8981(68)90280-5.

Gidlund, H., Hetta, M., Krizsan, S.J., Lemosquet, S. \& Huhtanen, P., 2015. Effects of soybean meal or canola meal on milk production and methane emissions in lactating dairy cows fed grass silage-based diets. J. Dairy. Sci. 98 , 8093-8106. https://doi.org/10.3168/jds.2015-9757.

Godden, S., Kelton, D., Lissemore, K., Walton, J., Leslie, K. \& Lumsden, J., 2001. Milk urea testing as a tool to monitor reproductive performance in ontario dairy herds. J. Dairy. Sci. 84, 1397-1406. https://doi.org/10.3168/jds.S00220302(01)70171-3.

Golombeski, G.L., Kalscheur, K.F., Hippen, A.R. \& Schingoethe, D.J., 2011. Slow-release urea and highly fermentable sugars in diets fed to lactating dairy cows. J. Dairy. Sci. 89, 4395-4403. https://doi.org/10.3168/jds.S00220302(06)72486-9.

Gonçalves, D.S, Pedreira, M.D.S., Azevedo, J.A.G., Del Rei, A.J., Silva, H.G.O. \& Silva, F.F., 2014. Replacement of soybean meal by conventional and coated urea in dairy cows: Intake, digestibility, production and composition of milk. J. Acta. Sci. Anim. Sci. 36, 71-78. http://dx.doi.org/10.4025/actascianimsci.v36i1.21314.

Gonzalez-Munoz, S., Sanchez, J., Lopez-Aguirre, S., Vicente, J. \& Pinos-Rodriguez, J., 2019. Ruminal fermentation and digestion of cattle diets with total and partial replacement of soybean meal by a slow-release urea product. J. Vet. Med. 64, 294-301. https://doi.org/10.17221/159/2018-VETMED.

Guo, K., Russek-Cohen, E., Varner, M. \& Kohn, R., 2004. Effects of milk urea nitrogen and other factors on probability of conception of dairy cows. J. Dairy. Sci. 87, 1878-1885. https://doi.org/10.3168/jds.S0022-0302(04)73346-9.

Hammon, D.S., Holyoak, G.R. \& Dhiman, T.R., 2005. Association between blood plasma urea nitrogen levels and reproductive fluid urea nitrogen and ammonia concentrations in early lactation dairy cows. J. Anim. Reproduct. Sci. 86, 195-204. https://doi.org/10.1016/j.anireprosci.2004.08.003.

Highstreet, A., Robinson, P.H., Robison, J. \& Garrett, J.G., 2010. Response of Holstein cows to replacing urea with with a slowly rumen released urea in a diet high in soluble crude protein. J. Livest. Sci. 129,179-185. https://doi.org/10.1016/j.livsci.2010.01.022.

Hristov, A.N. \& Ropp, J.K., 2003. Effect of dietary carbohydrate composition and cvailability on utilization of ruminal ammonia nitrogen for milk protein synthesis in dairy cows. J. Dairy Sci. 86, $2416-2427$. https://doi.org/10.3168/jds.S0022-0302(03)73836-3.

Huntington, G.B., Harmon, D.L., Kristensen, N.B., Hanson, K.C. \& Spears, J.W., 2006. Effects of a slow-release urea source on absorption of ammonia and endogenous production of urea by cattle. J. Anim. Feed. Sci. Technol. 130, 225-241. https://doi.org/10.1016/j.anifeedsci.2006.01.012

Ichihara, K. \& Fukubayashi, Y., 2010. Preparation of fatty acid methyl esters for gas-liquid chromatography. J. Lipid. Res. 51, 635-640. http://dx.doi.org/10.1194/Jlr.D001065 
Imaizumi, H., De Souza, J., Batistel, F. \& Portela Santos, F.A., 2015. Replacing soybean meal for cottonseed meal on performance of lactating dairy cows. J. Trop. Anim. Health Prod. 48, 139. https://doi.org/10.1007/s11250-0150933-1y

Inostroza, J.F, Shaver, R.D., Cabrera V.E. \& Tricárico, J.M., 2010. Effect of diets containing a controlled-release urea product on milk yield, milk composition, and milk component yields in commercial Wisconsin dairy herds and economic implications. J. Prof. Anim. Sci. 26, 175-180. https://doi.org/10.15232/S1080-7446(15)30577-5

Jeshari, M., Riasi, A., Mahdavi, A.H., Khorvash, M. \& Ahmadi, F., 2016. Effect of essential oils and distillation residues blends on growth performance and blood metabolites of Holstein calves weaned gradually or abruptly. J. Liv. Sci. 185, 117-122. https://doi.org/10.1016/j.livsci.2015.12.011

Jorritsma, R., Wensing, T., Kruip, T.A.M., Vos, P.L.A.M. \& Noordhuizen, J.P.T.M., 2003. Metabolic changes in early lactation and impaired reproductive performance in dairy cows. J. Vet. Res. 34, 11-26. DOI: 10.1051/vetres:2002054

Johnson, M.M. \& Peters, J.P., 1993. Technical note: an improved method to quantify nonesterified fatty acids in bovine plasma. J. Anim. Sci., 71, 753-756. https://doi.org/10.2527/1993.713753x

Joysowal, M., Tyagi, A.K., Tyagi, N., Kumar, S. \& Keshri, A., 2019. Use of slow release ammonia products in ruminant diet: A review. J Entomol Zool Stud. 7, 882-888.

Kara, U., Ayașan, T., Hïzli, H. \& Gök, K., 2011. Effect of ovsynch protocol on pregnancy rate in heifers and cows. J. Erciyes. Univ. Vet. Fac, 8, 1-8 (in Turkish).

Kertz, A.F., 2010. Review: Urea feeding to dairy cattle: a historical prospective and review. J. Pro. Anim. Sci. 26, 257272. DOI: https://doi.org/10.15232/S1080-7446(15)30593-3

Loest, C.A., Titgemeyer., E.C, Drouillard., J.S., Lambert, T.B.D. \& Trater, A.M., 2001. Urea and biuret as nonprotein nitrogen sources in cooked molasses blocks for steers fed prairie hay. J. Anim. Feed. Sci. Tech. 94,115-126. https://doi.org/10.1016/S0377-8401(01)00312-1

Lopes, J.C., Harper, M.T., Giallongo, F., Oh, J., Smith, L., Ortega-Perez, A.M., Harper, S.A., Melgar, A., Kniffen, D.M., Fabin, R.A. \& Hristov, A.N., 2017. Effect of high-oleic-acid soybeans on production performance, milk fatty acid composition, and enteric methane emission in dairy cows. J. Dairy Sci. 100, 1122-1135. https://doi.org/10.3168/jds.2016-11911

Ludden, P.A., Harmon, D.L., Huntington, G.B., Larson., B.T. \& Axe, D.E., 2000. Influence of the novel urease inhibitor N(nbutyl) thiophosphoric triamide on ruminant nitrogen metabolism: II. Ruminal nitrogen metabolism, diet digestibility, and nitrogen balance in lambs. J. Anim. Sci. 78,188-198. https://doi.org/10.2527/2000.781188x

Melendez, P., Donovan, A. \& Hernandez, J., 2000. Milk urea nitrogen and infertility in Florida holstein cows. J. Dairy Sci. 83, 459-463. https://doi.org/10.3168/jds.S0022-0302(00)74903-4

Millen, D.D., Pacheco, R.D.L., Arrigoni, M.D.B., Galyean, M.L. \& Vasconcelos, J.T., 2009. A snapshot of management practices and nutritional recommendations used by feedlot nutritionists in Brazil J. Anim. Sci. 87, 3427-3439. https://doi.org/10.2527/jas.2009-1880

Miranda, M.S., Arcaro, J.R.P., Saran Netto, A., Silva, S.L., Pinheiro, M.G. \& Leme, P.R., 2019. Effects of partial replacement of soybean meal with other protein sources in diets of lactating cows. Int. J. Biosci. 13, 1403-1411. https://doi.org/10.1017/S1751731118002926

Mousavi Seyyed Ali Kia, S.A., Teimori Yansari, A., Dirandeh, E. \& Irajian, G.H., 2019. Effects of different levels of replacement of slow-release urea with soybean meal on feed intake, blood parameters and performance of Holstein lactating cows in early lactation. J. Vet. Res, 74, 438-448. https://dx.doi.org/10.22059/jvr.2017.234213.2634

Munro, C. \& Stabenfeldt, G., 1984. Development of a microtitre plate enzyme immunoassay for the determination of progesterone. J. Endocrinol. 101, 41-49. https://doi.org/10.1677/joe.0.1010041\%20

Neal, K., Eun, J.-S., Young, A.J, Mjoun, K. \& Hall, J.O., 2014. Feeding protein supplements in alfalfa hay-based lactation diets improves nutrient utilization, lactational performance, and feed efficiency of dairy cows. J. Dairy Sci. 97, 7716-7728. https://doi.org/10.3168/jds.2014-8033

Nishimoto, H., Hamano, S., Hill., G.A., Miyamoto, A. \& Tetsuka, M., 2009. Classification of bovine follicle based on the concentrations of steroids, glucose and lactate in follicular fluid and the status of accompanying follicles. J. Reprod. Develop. 55, 219-224. https://doi.org/10.1262/jrd.20114

NRC., 2001. Nutrient requirements of dairy cattle. 7th ed. National Academy Press, Washington, DC.

Olmos Colmenero, J.J. \& Broderick, G.A., 2006. Effect of dietary crude protein concentration on milk production and nitrogen utilization in lactating dairy cows. J. Dairy. Sci. 89, 1704-1712. https://doi.org/10.3168/jds.S00220302(06)72238-X

Patra, A.K. \& Aschenbach, J.R., 2018. Ureases in the gastrointestinal tracts of ruminant and monogastric animals and their implication in urea-N/ammonia metabolism: A review. J. Adv. Res, 13, 39-550. https://doi.org/10.1016/j.jare.2018.02.005

Piccioli-Cappelli, F., Loor, J.J., Seal, C.J., Minuti, A. \& Trevisi, E., 2014. Effect of dietary starch level and high rumenundegradable protein on endocrine-metabolic status, milk yield, and milk composition in dairy cows during early and late lactation, J. Dairy Sci. 12, 7788-7803. https://doi.org/10.3168/jds.2014-8336

Piccione, G., Grasso, F., Fazio, F., Assenza, A. \& Caola, G., 2007. Influence of different schedules of feeding on daily rhythms of blood urea and ammonia concentration in cows. J. Biol. Rhythm. Res. 38, 133-139. https://doi.org/10.1080/09291010600913964

Puga, D.C., Galina, H.M., Perez-Gil, R.F., Sangines, G.L., Aguilera, B.A. \& Haenlein, G.F.W., 2001. Effect of a controlled-release urea supplement on rumen fermentation in sheep fed a diet of sugar cane tops (Saccharum 
officinarum), corn stubble (Zea mays) and King grass (Pennisetum purpureum). J. Small. Rumin. Res. 39, 269276. https://doi.org/10.1016/S0921-4488(00)00196-6

Rajala-Schultz, P.J., Saville, W.J.A., Frazer, G.S. \& Wittum, T.E., 2001. Association between milk urea nitrogen and fertility in Ohio dairy cows. J. Dairy. Sci. 84, 482-489. DOI: 10.3168/jds.s0022-0302(01)74498-0

Ribeiro, S.S., Vasconcelos, J.T, Morais, M.G., Ítavo, C.B.C.F. \& Franco, G., 2011. Effects of ruminal infusion of a slowrelease polymer-coated urea or conventional urea on apparent nutrient digestibility, in situ degradability, and rumen parameters in cattle fed low-quality hay. J. Anim. Feed. Sci. Technol. 164, 53-61. https://doi.org/10.1016/j.anifeedsci.2010.12.003

Russell, J.D., 2002. Rumen microbiology and Its role in ruminant nutrition. Ithaca, NY, USA.

Sabbia, J.A., Kalscheur, K.F., Garcia, A.D., Gehman, A.M. \& Tricarico, J.M., 2012. Soybean meal substitution with a yeast-derived microbial protein source in dairy cow diets. J. Dairy Sci. 95, 5888-5900. https://doi.org/10.3168/jds.2011-5237

Saleem, F., Ametaj, B.N., Bouatra, S., Mandal, R., Zebeli, Q., Dunn, S.M. \& Wishart, D.S., 2012. A metabolomics approach to uncover the effects of grain diets on rumen health in dairy cows, J. Dairy Sci. 95, 6606-6623. https://doi.org/10.3168/jds.2012-5403

Sarkar, M., Dutta Borah, B. \& Prakash, B., 2010. Efficacy of ovsynch protocol with antiprolactin treatment for timed artificial insemination during non-breeding seasons in yaks (Poephagus grunniens L.). J. Reprod. Domest. Anim. 45, 393-398. https://doi.org/10.1111/j.1439-0531.2008.01196.x.

Sevim, Ö. \& Önol, A.G., 2019. Supplemental slow-release urea and non-structural carbohydrates: effect on digestibility and some rumen parameters of sheep and goats. J. Anim. Plant. Sci. 29, 1-7.

Sinclair, L.A., Blake, C.W., Griffin, P. \& Jones, G.H., 2012. The partial replacement of soyabean meal and rapeseed meal with feed grade urea or a slow-release urea and its effect on the performance, metabolism and digestibility in dairy cows. J. Anim. Sci. 6, 920-927. https://doi.org/10.1017/S1751731111002485.

Tabatabaei, S., Mamoei, M. \& Aghaei, A., 2011. Dynamics of ovarian follicular fluid in cattle. J. Comp. Clin. Path. 20:591595. https://doi.org/10.1007/s00580-010-1038-x

Tamminga. S., 2006. The effect of the supply of rumen degradable protein and metabolisable protein on negative energy balance and fertility in dairy cows. J. Anim. Reprod. Sci. 96, 227-239. https://doi.org/10.1016/j.anireprosci.2006.08.003

Taylor-Edwards, C.C., Elam, N.A., Kitts, S.E., McLeod, K.R., Axe, D.E., Vanzant, E.S., Kristensen, N.B. \& Harmon, D.L., 2009. Influence of slow-release urea on nitrogen balance and portal-drained visceral nutrient flux in beef steers, $J$ Anim. Sci. 87, 209-221. https://doi.org/10.2527/jas.2008-0913

Tedeschi, L.O., Baker, M.J., Ketchen, D.J. \& Fox, D.G., 2002. Performance of growing and finishing cattle supplemented with a slow-release urea product and urea. Can. J. Anim. Sci. 82, 567-573. https://doi.org/10.4141/A02-018

Tikofsky, J. \& Harrison, G.A., 2007. Optigen II: Improving the efficiency of nitrogen utilization in the dairy cow. In: K.A. Jacques \& T.P. Lyons (eds). Nutritional biotechnology in the feed and food industries. Proc. Altech's 23rd Annual Symp. Alltech Inc., Lexington, KY, USA.

Tukey, J., 1949. Comparing individual means in the analysis of variance. Biometrics 5(2), 99-114. https://doi.org/10.2307/3001913.

Van Soest, P.J., Robertson, J.B. \& Lewis, B.A., 1991. Methods for dietary fiber, neutral detergent fiber, and nonstarch polysaccharides in relation to animal nutrition. J. Dairy. Sci. 74, 3583-3597. https://doi.org/10.3168/jds.S00220302(91)78551-2

Westwood, C.T., Lean, I.J. \& Garvin, J.K., 2000. Factors influencing fertility of Holstein dairy cows: A multivariate description. J. Dairy Sci. 85, 3225-3237. https://doi.org/10.3168/jds.S0022-0302(02)74411-1

Xin, H.S., Schaefer, D.M., Liu, Q.P., Axe, D.E. \& Meng, Q.X., 2010. Effects of polyurethane coated urea supplement on in vitro ruminal fermentation, ammonia release dynamics and lactating performance of Holstein dairy cows fed a steam-flaked corn-based diet. Asian-Aust. J. Anim. Sci. 23, 491-500. https://doi.org/10.5713/ajas.2010.90153 